\title{
Anthropogenic Changes of Caucasus Forest Landscapes
}

\author{
Dali Nikolaishvili*, George Dvalashvili \\ Department of Geography, Faculty of Exact and Natural Science, Tbilisi State University, Tbilisi, Georgia
}

\section{Email address:}

dali.nikolaishvili@tsu.ge (D. Nikolaishvili), giorgi.dvalashvili@tsu.ge (G. Dvalashvili)

\section{To cite this article:}

Dali Nikolaishvili, George Dvalashvili. Anthropogenic Changes of Caucasus Forest Landscapes. Earth Sciences. Special Issue: Modern Problems of Geography and Anthropology. Vol. 4, No. 5-1, 2015, pp. 54-59. doi: 10.11648/j.earth.s.2015040501.20

\begin{abstract}
Caucasus eco-region occupies more than 583 thousand sq km and are represented 25 types, 62 sub-types and 205 genera of landscapes. Due to several climatically contrasting regions the landscapes are quite diverse here. Sub-tropical humid conditions, also experiencing mostly hot, dry weather year-round dominate in the lowland and foothills of Caucasus. forests are mostly concentrated in low- and middle-mountain landscapes. Comparatively little are of forests are concentrated in the lowlands and plains. High volcanic plateaus of South Caucasus also are without forest areas and are represented by steppe vegetation. The main purpose of this work is to determine anthropogenic changes forest landscapes of Caucasus and to evaluate the degree of this changes. The trend of anthropogenic change of forests is observed almost on whole territory of eco-region, especially in plain areas. Therefore, the decreasing trend of forest area, phytomass amount, also the ecological functions are evident. The research is based on the landscape approach. A great set of field data were used. All these data were processed by means of GIS-technologies.
\end{abstract}

Keywords: Landscape approach, Forests, Ecological potential, Caucasus

\section{Introduction}

Spatial-temporal interpretation and evaluation of ecological potential of landscapes are one of the main objectives of geographical researches; it is very important for landscape planning and management, for formation of ecologically-oriented territories, for environment protection; also it can address new requirements of forecasting changes in the global environment in our planet. On the other hand, it shows current trends, passing in the landscapes. Such researches present an opportunity to create scientific basis for a sustainable use of natural resources. This issue is important from constructive point of view. At the same time evaluation of ecological potential of any territory is inevitable preconditions for landscape prognosis and working out of landscape planning scheme and future strategies.

Landscape potential is set of the resources, which is in use, or can be used in future for life improvement and economical development, and also it can be play specific social-economical role. Landscapes are differing from each other according to potential. Some landscapes can have one type of potential, another landscapes - set of these types. e.g. The main parts of Depression of South Caucasus, Ararati plain have very high agriculture potential, which is determined mainly by agri-climatic conditions and soil productivity.

A lot of researches have been regarded studying different parts of Caucasus Ecoregion. There are reflected distinct questions; such are natural conditions, flora and fauna, protected area systems, conservation plans, landscape changes, etc. But many aspects still remain uninvestigated. Among them is evaluation of ecological potential. Therewith, the plain landscapes are studied better, than mountains landscapes. It's caused by the following factors: a) majority of the physical-geographical stationers (meteorological, hydrological, etc.) are mainly located within the limits of plain, in surrounds of settlements; b) relatively simplicity of studying of plain landscapes; c) here are located the main agricultural lands, etc.

\section{Study Area}

First, confirm that you have the correct template for your paper size. This template has been tailored for output on the A4 paper size.

Traditionally is considered that Caucasus is located between the Kuma-Manich depression and the Turkey-Iran state border on 440 thousand sq $\mathrm{km}$ area. The west and east boundaries of Caucasus are Black, Azov and Caspian Seas. So, it includes 4 countries: whole areas of Georgia, 
Azerbaijan, Armenia, and part of territories of Russia (North Caucasus). But Caucasus as Ecoregion encompasses more than 583 thousand $\mathrm{sq} \mathrm{km}$ contains the territories of six countries: Georgia, Azerbaijan, Armenia, and part of territories of Russia, Turkey and Iran.

Caucasus is a region where forest is one of the most important biotope for ecological view of point. Caucasus is one of the most biologically rich regions on Earth. It is ranked as a planet's 25 most diverse and endangered hotspots by conservation International $(\mathrm{CI})$ and Critical Ecosystem Partnership Fund (CEPF). Also Caucasus is one of WWF's Global 200 vulnerable Eco-regions. Here, 6,500 species of vascular plant are found and the highest level of endemism in the Temperate Zone of the Northern Hemisphere [1].

One of the major peculiarities of the Caucasus Ecoregion is the existence of comparatively large amount of virgin ecosystems, mainly in mountainous area. The most untouched area is high mountain glacial-nival and middle-mountain landscapes with beech and dark-coniferous forests. Despite of relative big area of untouched landscapes, there are a number of environmental problems connected with land degradation, desertification, decreasing of biodiversity, loss of species and habitats, and deforestation. In some places of Caucasus decreasing trend of forest area is observed. The Caucasus Ecoregion has always been a region of ongoing major geo-dynamic processes, such are: avalanches, mudflows, floods, and others, caused by the influence of natural and anthropogenic factors too. Furthermore, scientists consider that the destruction of forests in different parts of the Caucasus Ecoregion (Javakheti plateau, Shida Kartli ans Kvemo Kartli plains, northern slopes of the Great Caucasus and areas between the rivers Zelenchuk and Baksan) is connected with human activities. Many historical and literary documents indicate that formerly forest-covered areas rich in fauna are now occupied by settlements, also semi-desert, steppes, shrubs, degraded lands, and at the best - thinned forest area.

The trend of decreasing of forest areas is observed almost on whole territory of Ecoregion, which differs according to different landscapes and sub-regions. Destruction of the forests became very intensive in the 19th and the first part of the 20th centuries, when extensive logging was noticeable in the region. In the 1970-80s, mass woodcuts were limited due to import of timber from Siberia and Far East (Russia) and also due to adoption of Forestry codes, on the base of which the most part of mountain forests were belonged to the first category forests (where commercial logging was banned). That's why mountain forests of Caucasus remained relatively untouched. In 1990s on the background of socio-economic crisis in the former Soviet countries, the increase in population impact on forestry resources was obvious. The highest quality and valuable species have been cut. As result the area of high-density forests have been considerably reduced [2]. On the other hand, transition period was also followed by a decline in population size in some sub-regions of the Caucasus. So, environmental pressure was reduced and the states of the landscapes were improved in terms of some aspects. On the background of depopulation area of forestlands in some places of Caucasus began to increase. Pines and other rapidly growing species occupied the places of former arable lands, pastures and settlements. These followed by increasing forested lands. In modern period agriculture and infrastructure development, also overgrazing have resulted in decline of forest of Caucasus. So, all above mentioned factors contribute to decrease the productivity and regeneration rate of forests in different places of Caucasus. Therewith, forest fauna have been extinct, or migrated from their habitats. But it will be mentioned that the problem of deforestation and forest degradation have not been so acute for the Caucasus as in many other region of world.

\section{Materials and Methods}

The main specificity of this research is the use of landscape approach, not only using administrative units. The research method is based on the concept of spatial-temporal analysis and synthesis of Natural-territorial Complexes (NTCs), developed in 1980s at Tbilisi State University (TSU) under the guidance of Prof. N. Beruchashvili. The main value of the concept is that it enables to study natural resources, peculiarities of structure and functioning of landscapes, degree of transformation of territory, and other questions, applying one methodology [3]. The special place is assign to geomass, including phythomas, which able to determine the bio-resources, modern condition, sensitivity, and finally ecological potential of landscapes. Landscape approach gives possibility to determine not only the amount of pythomass, but also supply of phytomass which indicates its real size in the landscape area (in tones). This gives facility to fix quite exactly the resources of phytomass in different landscapes and to elucidate several spatial peculiarities. So, such approach gives possibility to reveal regional and mosaic territorial features of territory.

There is no perfect mathematical or cartographic method of evaluating ecological potential of different territorial units (administrative units, landscapes). Therefore, it's important to develop method for multifactor analysis, which allows objective-evaluating process. We used many different parameters for defining ecological potential of landscapes. At the next stage normalized quantities of the parameters were defined and integral parameter was calculated. Besides, it's possible to define share of each parameter in the integral parameter.

The research was conducted in several stages:

- Correlating the data diffused in branch geographical literature and creating the DB of Caucasus Landscapes of Ecoregion. Data have been grouped according to 6 countries and landscapes;

- Identification of factors and indicators, determining ecological potential of landscapes;

- Determining and analyzing of ecological parameters of Landscapes of Caucasus Ecoregion.

In the work mainly are used field materials of LAB for Studying Environmental Conditions by Space methods 
(TSU). These researches were conducted in different part of Caucasus Ecoregion during long-term period. There were used also forestry data, scattered in different scientific sources and institutions [4-10]. In addition to this are used the data of the local and international projects (WB, WWF, UNEP, CENN Caucasus, WWF, CEPF), in which participated the authors.

In this research data are examined as for Caucasus, also for whole Caucasus Ecoregion. Data are given for both of above mentioned regions and in some cases, are given according to some landscapes (on the level of type, sub-type, or genera of landscapes). Study was carried out on the base of Landscapes Maps of Caucasus Ecoregion and Caucasus [11], where the smallest unit of landscapes is genera.

\section{Results}

\subsection{Key Oro-Climatic Barriers for Landscape Differentiation of Caucasus Eco-Region}

The differentiation of landscapes of Caucasus Ecoregion is determined by existence of large oro-climatic barriers, such are Great Caucasus Range, Trans-Caucasian Mountain barrier and Javakheti-Armenian Volcanic Highland [5]. Another important key oro-climatic units are: Talish Mountains and Western Alborz (Elburz) Mountains.

Great Caucasus Range, which extends from Tamani peninsula to Apsheron peninsula approximately on 1,500 kilometers, with highest peak more than 5,000 meter above the sea in central part of range, is the main barrier, dividing whole Caucasus on two main parts: North Caucasus and South Caucasus. It blocks the north-south movement of air masses. The main important has the blocking of penetration of cold north air masses. North Caucasus is located in temperate zone and South Caucasus - in Sub-tropical zone. Therefore, plains and foothills of North Caucasus are represented by temperate climate and South Caucasus - by sub-tropical climate. The second significant oro-climatic is Trans-Caucasian Mountain barrier, which extends mainly from the north to the south and particularly from the north-east to the south-west. This mountain barrier is compound by Stavropol highland, part of central section of Great Caucasus (watershed of Black and Caspian Seas), Likhi Range, eastern section of Lesser Caucasus, Arsiani and Pontic (Dogu Karadeniz) mountains. This barrier, blocking the penetration of western humid air masses, makes also two part of Caucasus eco-region: humid western part with refugium for plants of Tretial period (Colchic flora) and relatively dry eastern part. Thus, humid and semi-humid landscapes are mainly represented in the western part of Caucasus eco-region and semi-humid, semi-arid and arid landscapes are chiefly distributed in the eastern part of Caucasus eco-region. As a result, the biggest area of forest is represented in the western part of eco-region. Another significant oro-climatic barrier is the outside edge of Javakheti-Armenian volcanic highland, which separate much dry south, where semi-arid and arid landscapes are located.
Talish and western Alborz Mountains, located in the southeastern part of Caucasus, are extended along the Caspian Sea. Its influence makes the difference between the slopes inverted toward the Caspian Sea and the inner part of eco-region. The first one is the refugium for plants of Tretial period (Hyrcanic flora).

\subsection{Territorial Distribution of Forest Landscapes in the Caucasus Ecoregion}

There are 2 classes, 25 types, 62 subtypes, 205 genera and more than 150 species of landscapes in Caucasus Ecoregion. Forests are represented in 16 types, 39 subtypes and 105 genera of landscapes. Here are presented not only thick forests, but also sparse wood, dwarf and elfin, derivative and degraded forest areas.

The Caucasus Ecoregion is rich in forests. The total area of forests covers $18.52 \%$ of the total land area of the Ecoregion and it is considered as the most important for biodiversity conservation [12]. Most Caucasus forests are located in Russia and Georgia. The biggest area of forests is in the North Caucasus (Russia) and it numbers more than $2.8 \mathrm{mln}$ ha (Fig. 1). The second place occupy Georgia with more than $2.7 \mathrm{mln}$ ha forest area. But North Caucasus has very low percentage of forest cover (less than $12 \%$ ). The smallest area of forest comes on Armenia and it makes only 450 thousand ha. Percentage of forest cover is the lowest here too. Another picture is observed according to percentage of forest land. Georgia has a highest percentage of forestlands and it makes nearly $40 \%$ of whole territory of country.

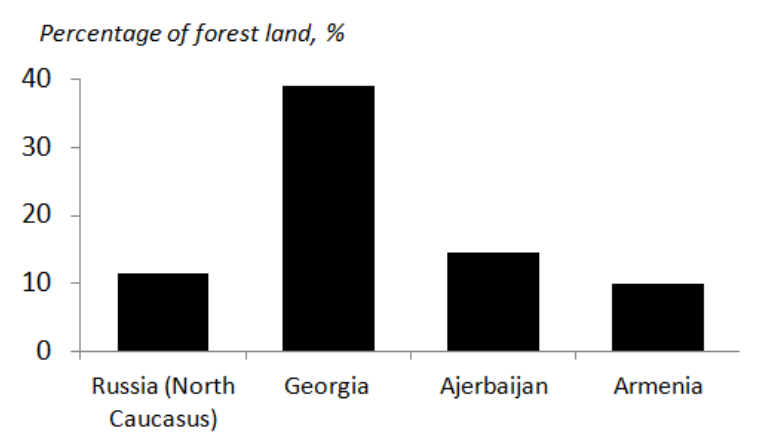

Figure 1. Forest Area of Caucasus by Countries

Most forest of Caucasus Ecoregion is located in mountainous area (Fig. 2), particular in middle-mountain landscapes, primarily found between altitudes of $800(1,000)$ $-1,800(2,000) \mathrm{m}$.

Here is well-expressed vertical zonality of forest. In the mountains the low altitudes (800-1,200 m) occupy mainly broad-leaved forests - oak (Quercus iberica, Q. imererina, Q. pontica, Q. pedunculiflora), poplar (Populis tremula), oak-hornbeam (Carpinus caucasica, C. orientalis (Castanea sativa), chestnut forests. The beech (Fagus orientalis) forests and in the western part of Ecoregion - dark-coniferous (fir, spruce-fir) and beech-dark coniferous forests appear at the middle altitudes $(1,400-1,800 \mathrm{~m})$. In some gorges dark coniferous forests are droping out. The upper timberline 
$1,850-2,000(2,600)$ is represented by dwarf and elfin trees beech and birch (C. betula), also pine (Pinus caucasica, Pinus kockiana) and oak (Quercus macranthera, Q. pontica).

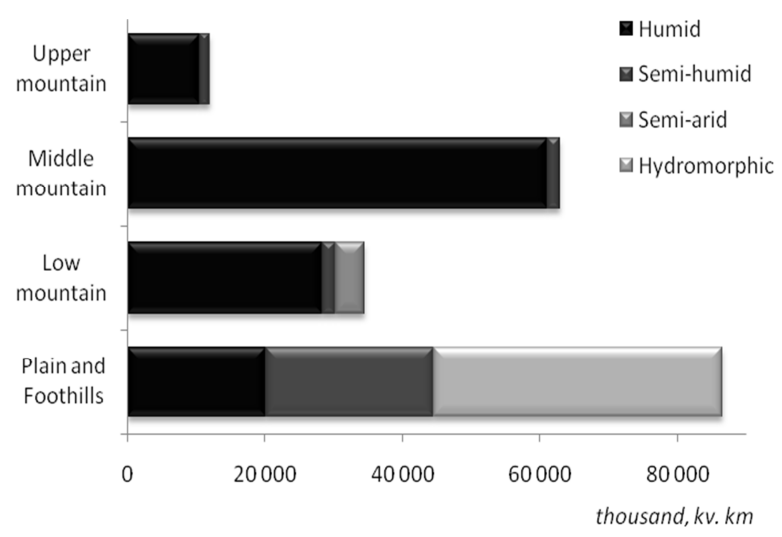

Figure 2. Forests Landscapes of Caucasus Ecoregion

Broadleaf forests play the leading role in the region's forestry. The most important role has beech forests, accounting the biggest area and timber in the region. In the western part of Caucasus Ecoregion mountain forests are characterized by Colchic evergreen understory.

Plain forests are significantly changed under the influence of human activity. In western central part of Colchic lowland alder forests, somewhere with swamps are widespread, while in other parts of lowland - only fragments of forests are represented. Arid open forests, consisting of Pistacia mutica, juniper, pistachio (Phistacia mutica), also Georgian maple (Acer ibericum), Araxian oak (Quercus araxina) are widespread in eastern part of South Caucasus.

Low river terraces and riparian forests, growing on alluvial moist soils, consist of alder, lowland oaks (Q. robur, Q. petraea), wing nut, etc. Only the fragments of these forests are preserved in the Kura, Iori, Aragvi, Alazani-Agrichai, Samur rivers and its attribute's valleys to this present day.

Caucasus Ecoregion forests are key habitat for local animal species such as turs, Gmelin' mouflon, Caucasian snowcock, Caucasuan black grouse. Darevsky's viper, bezoar gpat, chamois, etc.

\subsection{Factors influencing on Ecological Potential of Landscapes}

Ecological potential of landscapes requires taking into consideration various factors. These factors can be grouped into some main groups. Each of these factors incorporate several indicators, in particular: modern condition, sensitivity, recreational functions of landscapes, etc..

Among the landscape-ecological indicators one of the important roles is dedicated to modern condition (degree of anthropogenic transformation) of landscapes, because in turn it needs analyze a lot of factors, such are population density; share of agricultural lands, existence of polluted industrial enterprises, transport network, etc. On the other hand, a great importance has existence of virgin territories, protected area, ecologically "clean" sections of land, etc. So, according to available data 6 categories of modern condition of landscapes of Caucasus Ecoregion were allocated: practically completely changed, mostly changed, moderately changed, less-changed and very less-changed landscapes. The less-changed and very less-changed categories mainly belongs high-mountain glacial-nival, middle-mountain beech and dark-coniferous forest landscapes, and also plain and foothill landscapes with swamps, or semi-deserts. Plain and foothill forest landscapes belong to these categories generally only within the protected area.

It should be noted that the middle-mountain forest landscapes have mostly maintained their primary natural condition and are distinguished with the lowest degree of changes especially (not counting the high sub-nival and nival landscapes).

Another important indicator influencing on the ecological potential is landscape diversity. Located in the central part of the Alpine-Himalayas mountain chains, Caucasus Ecoregion is characterized by high landscape diversity and according this index it occupies one of the highest ranks in the world. It is determined by location of region at the junction of sub-tropical and moderate zones, the border between them passes along the Main Caucasus Range. A broad spectrum of landscapes is found here, starting from extra-humid and humid to arid, from plain and foothills sub-tropical to high-mountain glacial-nival. Almost every climatic zone is represented here, except for savannas, tropical forests and deserts. There are 2 classes, 25 types, 62 subtypes, 205 genera and more than 150 species of landscapes in Caucasus eco-region [1]. Based on rough calculations, over $40 \%$ of landscape types are existent here and occupy only $0.5 \%$ of the global land area [Beruchashvili et al. 2002]. The high diversity is characterized for Caucasus separately. Here are 2 classes, 20 types, 40 sub-types, and genera of landscapes [11].

High diversity of landscapes is defined by different factors. The most important between them are: a) proximity and distance from Black sea; b) exestance of oro-climatic barriers, forming damp climate and rather large rain shadow that minimizes precipitation; c) distribution of volcanic and carbonate rocks; paleo-geographic development of the region; d) proximity of different floristic and regions, which is represented by elements of Colchic, Caucasus, Boreal, Mediterranean, and West Asian flora; e) anthropogenic factors that have transformed vegetation cover in some areas.

Landscape diversity calculated by countries shows that Georgia is marked by highest level according to landscape genera and it outstrips all other countries. Therewith, Georgia ranks first place in the world according to landscape diversity per unit of the territory. But according to landscape types and sub-types top ranking belongs to Azerbaijan (Beruchashvili 2000). The high level of landscape diversity is characterized for Turkey, particularly in those places, where Colchic, Mediterranean and Sub-Mediterranean landscapes convergence. This feature is expressed even in forest landscapes, represented more interchanging of different forest biomes. 
High amount of phytomass is one of the significant indicators, showing the ecological potential of landscapes. The distribution of phytomass amount of forests shows the same situation as forest cover distribution. e.g. the biggest amount of phytomass is concentrated in the North Caucasus and Georgia. In mountain forest landscapes the widest range of phytomass is characterized for the low-mountain forest landscapes where we can found areas with less than $50 \mathrm{t} / \mathrm{ha}$ and with more than $600 \mathrm{t} / \mathrm{ha}$ amount of phytomass too. The highest amount of phytomass is characteristic for the middle-mountain forest dark-coniferous and beech-dark coniferous landscapes in western part of Caucasus Ecoregion and it makes up $500 \mathrm{t} / \mathrm{ha}$ and higher, at average. In some area it can exceed 700-800 t/ha. The middle-mountain forest landscapes with the prevalence of beech forests is marked by second place (300-500 t/ha) and the third - lower mountain Colchic landscapes $(250-300 \mathrm{t} / \mathrm{ha})[5,8,13]$.

Table 1. Some Peculiarities of Landscapes of Caucasus Ecoregion according to Ecological Potential

\begin{tabular}{lllll}
\hline $\begin{array}{l}\text { Level of Ecological } \\
\text { Potential }\end{array}$ & $\begin{array}{l}\text { Number of Landscape } \\
\text { Types/Sub-types }\end{array}$ & Area, thousand square km & $\begin{array}{l}\text { Average Amount of } \\
\text { Phytomass, t/ha }\end{array}$ & $\begin{array}{l}\text { Degree of Anthropogenic } \\
\text { Transformation }\end{array}$ \\
\hline Very high & $4 / 7$ & 63.4 & $300-500$ & Insignificant \\
High & $5 / 8$ & 38.6 & $200-300$ & Insignificant \\
Moderate & $1 / 8$ & 16.6 & $150-250$ & Significant \\
Low & $4 / 7$ & 14.8 & $75-150$ & Significant \\
Very low & $2 / 9$ & 16.4 & $50-75$ & Very significant \\
\hline
\end{tabular}

Soil productivity is also very factor determining ecological potential of landscapes, because it plays important role in the biological cycle and influences on the physic-geographical processes. Humus amount is an obvious indicator of the resource potential of a landscape. Since humus is so important in the biological cycle, changes in its amount testify to changes in the environment. Therefore, for the determination of the scope of these changes and the status of the environment, studies of humus and its distribution in landscapes are of great significance [14].

Sensitivity also refers on the ecological potential of landscapes. The main criteria determining landscape sensitivity are: steepness of slope, regime of migration, geological structure, geo-dynamical processes, exposition of slopes, type of relief, depth of soil, etc. So, according these criteria for low-sensitive landscapes is characterized low steepness of slope (less than $5^{0}$ ), autonomic and super-aqual regime of migration, high-dense rocks, etc. In contrast, high steepness of slopes, trans-eluvial regime of migration, easy-destroyed rocks, spreading of badlands and eroded soils is character for low-sensitive landscapes. The most low-sensitive area is located in high-mountain landscapes, where interchanges steep slopes and rocks, low-depth and eroded soils, etc. Due to distribution of steep slopes (with steepness more than 20-30 ) the high-sensitive areas are inherent for middle-mountain forest landscapes. But at the same time existence of high trees, complexity of forest vertical structure increases its stability. Therefore, it is important to protect and reserve these forests.

Recreational function of landscapes is determined by aesthetic and sanitary value, also abundance of cultural-historical monuments. The important role plays the fact, which under anthropogenic pressure the aesthetic value of landscapes doesn't destroy. Climatic conditions, water supply, mineral resources, uncial flora and fauna and many others increase recreational value of landscapes.

So, these factors and indicators was was selected to determine the ecological potential of landscapes.

\subsection{Classification of Caucasus Ecoregion's Landscapes According to Ecological Potential}

Caucasus Ecoregion's forest Landscapes considerable differ from each other according to ecological potential.

Very high ecological potential is character for the most part of middle-mountain forests with prevalence of beech and dark-coniferous fore. They make the significant part of the forest of the Ecoregion (Table 1) and are mainly located on the northern and southern slopes of Great Caucasus, on the Northern and eastern slopes of Lesser Caucasus, on the northern slopes of Pontic (Dogu Karadeniz) and Alborz Mountains. These landscapes are represented with very small density of population also very small percent of cultivated land. Here is concentrated 300-500 t/ha phytomass, in some places more than 600-700 t/ha. Especially the highest amount of phytomass is characteristic to middle-mountain forest dark-coniferous landscapes in western part of Ecoregion and it makes up $500 \mathrm{t} / \mathrm{ha}$ and higher, at average. But in some places it makes more than $700-800 \mathrm{t} / \mathrm{ha}$. Annual productivity of phytomass makes 15-20 t/ha yearly in West Georgia. This is determined by duration of productive daily geo-conditions of landscapes, during of which active bio-production is conducted [8]. The duration such geo-conditions makes more than $50 \%$ of year [13]. Located on the steep slopes they play a remarkable role in protecting of soil, regulating water, and altogether in conservation of environmental-protecting functions. Very high ecological potential is determined by high bio-productivity, low anthropogenic transformation, high recreational and environmental protection functions, etc. The highest ecological potential is character also for the plain and foothills, also low-mountain forest landscapes of protected areas.

Very high ecological potential is character for a significant area of Ecoregions' forests, represented by part of low-mountain and middle-mountain landscapes. In comparison with above-mentioned landscapes, the forest area 
here has significantly declined, which is caused firstly by anthropogenic impact on the gently sloping areas; therefore, some types of geodynamical catastrophic processes are developed near populated areas.

Moderate ecological potential is typical for a small part of the low-mountain forest landscapes. Part of these landscapes are in the critical conditions.

Low ecological potential is peculiar to upper mountain forest landscapes. The highest humus amounts in the forest landscapes of Ecoregion is registered in the upper mountain cool temperate humid forest and humid subalpine landscapes, where the humus amounts, on average, to $300 \mathrm{t} / \mathrm{ha}$ in the $1 \mathrm{~m}$ thick soil layer. Such high size is stipulated by many physiographic factors that inhibit the decomposition of organic residues and by the development of the dense grass cover. But on the other hand, the comparatively difficult situation is found in some parts of these landscapes, where geo-dynamic processes - landslides and mudflows are widespread, inflicting huge damage to the local economy and infrastructure. Due to anthropogenic pressure the area of these landscapes is significant decreasing. These landscapes play very important role for the defense of lower located landscapes.

Very low ecological potential is peculiar to high mountain sub-alpine landscapes with dwarf and elfin forests, which is found throughout the whole Ecoregion. This zone is pointed with its huge diversity of flora and great abundance of endemic and relict species. But on the other hand, the upper timberline of the forest areas is frequently replaced by subalpine meadows. Some areas are inhabited seasonally. Forest logging and overgrazing resulted in important landscape changes - weakening of conservation functions. Severe climatic conditions, high snow cover in winter and avalanches, as well as other geo-dynamic processes block self-restoration of the landscape. The functionary of the landscapes is substantial determined by socio-economic processes. Geo-dynamic processes are widespread and cause huge changes. The landscapes are considerably changed under the influence of illegal logging, overgrazing, finally irrational use of land. Thus, the condition of landscapes is determined basically by socio-economic processes.

\section{Conclusions}

On the basis of the concept of spatial-temporal analysis and synthesis of landscapes a number of some important results have been obtained:
- Concept of spatial-temporal analysis and synthesis of Natural-territorial Complexes is representative for the evaluation of the ecological potential of landscapes;

- The method for determining ecological potential of landscapes was elaborated on the grounds of multifactor analysis;

Based on the branch geographical data systematization, their correlation to landscape units and creation of uniform database of geographical inventory the degree of landscape changes was revealed, as well as some peculiarities of territorial distribution of Georgia's landscapes changes.

\section{References}

[1] An ecoregional conservation plan for the Caucasus. Second ed. May, 2006.

[2] WB/State Forestry Department, Georgia, 1997.

[3] Methodology of landscape-geophisical researches and mapping of conditions of Naturak-territorial complexes. Tbilisi: TSU, 1983. In Russian.

[4] Atlas of Forests of USSR. Moscos, 1973. In Russian.

[5] Beruchashvili N. Caucasus: Landscapes, Models, Experiments. UNEP-GRID, 1995. In Russian.

[6] Forests of USSR. vol. 3. In Russian.

[7] Kvachakidze R.K. High latitude forest of southern slope of Great Caucasus and the main directions of vegetation fluctuations. Tbilisi, 1979 (In Georgian).

[8] Tediashvili A.G. 1984. Research of phytomass as landscape-geophysical parameter of NTCs and it's conditions. Tbilisi: TSU. In Russian.

[9] Tugushi K.L. 1972. Forests of Abkhazeti. Sukhumi. In Russian.

[10] Orlov A.I. Decidiuous forests of North-west part of Great Caucasus. Moscow, 1953. In Russian.

[11] Beruchashvili N.L. Landscape Map of Caucasus. T 1979, scale $1: 1,000,000$.

[12] Ecoregion Conservation Plan for the Caucasus. 2012 revised and updated edition. WWF.

[13] Nikolaishvili D. A. Spatial-Temporal Analysis of Georgia's Landscapes. Tbilisi State University Publishing House, 2009. In Georgian.

[14] Nikolaishvili D. A., Matchavariani L. G. Humus Reserves and Their Distribution in the Landscapes of Georgia. Eurasian Soil Science, 2010, Vol. 43, No. 1, pp. 39-48. 